\title{
Structural, Morphological and Vibrational Properties of Titanate Nanotubes and Nanoribbons
}

\author{
Bartolomeu C. Viana, ${ }^{b}$ Odair P. Ferreira, ${ }^{*, a}$ Antonio G. Souza Filho, ${ }^{b}$ \\ Josue Mendes Filho ${ }^{b}$ and Oswaldo L. Alves ${ }^{a}$
}

\author{
${ }^{a}$ Instituto de Química, Universidade Estadual de Campinas, CP 6154, 13083-970 Campinas-SP, Brazil \\ ${ }^{b}$ Departamento de Física, Universidade Federal do Ceará, CP 6030, 60455-900 Fortaleza-CE, Brazil
}

\begin{abstract}
Este trabalho relata o estudo das propriedades estruturais, morfológicas e vibracionais dos nanotubos e das nanofitas de titanato obtidos a partir de estruturas bidimensionais por meio de tratamento hidrotérmico do $\mathrm{TiO}_{2}$ em solução aquosa de $\mathrm{NaOH}$. As propriedades físicas destas nanoestruturas, como preparadas e tratadas termicamente, são discutidas e comparadas com seus similares "bulks" $\left(\mathrm{Na}_{2} \mathrm{Ti}_{3} \mathrm{O}_{7}\right.$ e $\left.\mathrm{Na}_{2} \mathrm{Ti}_{6} \mathrm{O}_{13}\right)$. Os resultados obtidos por várias técnicas de caracterização nos permitem concluir que as paredes dos nanotubos e das nanofitas, como preparados, são isoestruturais ao composto $\mathrm{Na}_{2} \mathrm{Ti}_{3} \mathrm{O}_{7}$. Contudo, nos nanotubos as ligações químicas são deformadas por causa da curvatura das paredes, enquanto nas nanofitas as camadas apresentam apenas uma desordem estrutural provocada pelo efeito de tamanho. As características térmicas das nanofitas são similares àquelas observadas para os nanotubos, nos quais as mudanças estruturais e morfológicas levam para a formação de grandes bastões (bulks) com uma mistura de fase $\mathrm{Na}_{2} \mathrm{Ti}_{3} \mathrm{O}_{7}$ e $\mathrm{Na}_{2} \mathrm{Ti}_{6} \mathrm{O}_{13}$. Concluímos que os nanotubos e as nanofitas de titanato têm a mesma composição química, igual a $\mathrm{Na}_{2-\mathrm{x}} \mathrm{H}_{\mathrm{x}} \mathrm{Ti}_{3} \mathrm{O}_{7} \cdot \mathrm{nH}_{2} \mathrm{O}(0 \leq \mathrm{x} \leq 2)$. Também podemos sugerir que a espectroscopia Raman pode ser usada para uma fácil e rápida identificação das mudanças morfológicas e estruturais das nanoestruturas de titanato.
\end{abstract}

This work reports the structural, morphological and vibrational properties of titanate nanotubes and nanoribbons obtained from bidimensional structures by hydrothermal treatment of $\mathrm{TiO}_{2}$ in aqueous $\mathrm{NaOH}$ solutions. The physical properties of these as-synthesized and heat-treated nanostructures are discussed in comparison with their bulk $\left(\mathrm{Na}_{2} \mathrm{Ti}_{3} \mathrm{O}_{7}\right.$ and $\left.\mathrm{Na}_{2} \mathrm{Ti}_{6} \mathrm{O}_{13}\right)$ counterparts The results obtained from several characterization techniques allowed to conclude that the layers of both as-synthesized nanotubes and nanoribbons are isostructural to the $\mathrm{Na}_{2} \mathrm{Ti}_{3} \mathrm{O}_{7}$ compound. However, in the nanotubes, the chemical bonds are deformed because of the curvature of walls while in the nanoribbons the layers present structural disorder due only the size effects. The thermal behavior of titanate nanoribbons is similar to those observed for titanate nanotubes. When thermally treated titanate nanoribbons change to bulk with a phase mixing of $\mathrm{Na}_{2} \mathrm{Ti}_{3} \mathrm{O}_{7}$ and $\mathrm{Na}_{2} \mathrm{Ti}_{6} \mathrm{O}_{13}$. We conclude in this work that the chemical composition of both the titanate nanotubes and the nanoribbons is the same, $\mathrm{Na}_{2-\mathrm{x}} \mathrm{H}_{\mathrm{x}} \mathrm{Ti}_{3} \mathrm{O}_{7} \cdot \mathrm{nH}_{2} \mathrm{O}(0 \leq \mathrm{x} \leq 2)$ and Raman spectroscopy can be used for an easy and quick identification of both morphology and structure changes of the nanosized titanates.

Keywords: titanium oxide, titanate nanostructures, thermal treatment, phase transformation, spectroscopy

\section{Introduction}

Intensive investigations have been carried out on the physical and chemical properties of inorganic nanosized materials in the recent years. ${ }^{1}$ Researchers are realizing that one-dimensional nanostructures made from inorganic materials have intriguing properties different

\footnotetext{
*e-mail: odair@iqm.unicamp.br
}

from those of carbon nanostructures and thus have a variety of potential applications. ${ }^{2,3}$ In particular, titanate nanostructures have received a great deal of attention, in part because titanate nanomaterials have a large surface area that leads to a wide variety of applications, including secondary lithium batteries, dye sensitized solar cells, photocatalysts, and sensors. ${ }^{4-7}$ Titanate nanotubes have also been tested for use as catalysts in heterogeneous photocatalysis and have shown excellent performance for 
degrading textile dyes, which makes them very important ecomaterials. ${ }^{8,9}$

Titanate nanotubes and nanoribbons have mostly been prepared through hydrothermal treatment of $\mathrm{TiO}_{2}$ powders in aqueous $\mathrm{NaOH}$ solutions. ${ }^{10}$ This method is very simple, inexpensive and efficient for obtaining samples with good morphological yields. However, the formation mechanism, composition and atomic structure of the titanate nanotubes obtained by this method are not yet well-defined and these issues have been the subject of intense debate in the literature. ${ }^{11-15}$ What is consensus among different groups is that hydrothermal treatment induces the formation of an intermediate layered titanate and that the nanotubes are formed by rolling up the layers originating from this layered intermediate structure, thus forming a scrolllike geometry. ${ }^{13-16}$ On the other hand, there is a strong controversy regarding the composition and microscopic formation mechanism whereby nanostructures with different morphologies, such as nanotubes, nanorods, nanofibers or nanoribbons, are prepared using a similar hydrothermal process. It was observed that the reactive environment plays an important role in morphology control and by adjusting the parameters of the hydrothermal process, such as temperature and time, it is possible to obtain nanosized titanates in different morphologies. ${ }^{10,17-22}$

A new chemical composition was proposed for the as-prepared titanate nanotubes. ${ }^{19}$ The composition $\mathrm{Na}_{2-\mathrm{x}} \mathrm{H}_{\mathrm{x}} \mathrm{Ti}_{3} \mathrm{O}_{7} \cdot \mathrm{nH}_{2} \mathrm{O}(0 \leq \mathrm{x} \leq 2)$, where $\mathrm{x}$ depends on the washing conditions was recently proposed, based on chemical reactions and thermal decomposition properties. ${ }^{19,23}$ Furthermore, the nanotube walls and nanoribbons should have atomic structures similar to those observed in the layers of $\mathrm{Na}_{2} \mathrm{Ti}_{3} \mathrm{O}_{7}$ trititanate bulk. The titanate nanotubes would be formed by exfoliation of lamellar structure into single sheets between (100) planes followed by the wrapping of these planes into a scroll-like geometry. ${ }^{13-16,19,23,24}$ The nanoribbons would be formed through cutting of layers between (100) and (010) planes followed by their stacking in the (001) direction. ${ }^{24}$

In this paper, we present studies of structural, morphological and vibrational properties of different titanate nanostructures (nanotubes and nanoribbons). Based on the results obtained by several techniques, we show that both the morphology and structure of the titanate nanotubes (hereafter NTTiOx) and nanoribbons (hereafter NRTiOx) prepared by Kasuga's method can be well characterized by vibrational spectroscopy. ${ }^{10}$ Based on chemical analysis and thermal treatment results, we show that similar to NTTiOx, the NRTiOx walls have a $\mathrm{Na}_{2-\mathrm{x}} \mathrm{H}_{\mathrm{x}} \mathrm{Ti}_{3} \mathrm{O}_{7} \cdot \mathrm{nH}_{2} \mathrm{O}$ chemical composition and that the symmetry of the atomic arrangements in the layers is similar to that of a $\mathrm{Na}_{2} \mathrm{Ti}_{3} \mathrm{O}_{7}$ trititanate bulk. ${ }^{19}$ Temperature-dependent data indicate that the atomic layers of the nanoribbons undergo the transitions to a mixing of the $\mathrm{Na}_{2} \mathrm{Ti}_{3} \mathrm{O}_{7}$ and $\mathrm{Na}_{2} \mathrm{Ti}_{6} \mathrm{O}_{13}$ bulk phases. This structural change is similar to those observed to $\mathrm{Na}_{2} \mathrm{Ti}_{3} \mathrm{O}_{7}$ bulk when thermally treated in the same conditions. ${ }^{25}$

\section{Experimental}

All chemicals (reagent grade, Aldrich, Merck or Baker's Analyzed) were used as received, without further purification processes. All solutions were prepared with deionized water.

\section{Nanosized titanates preparation}

Titanate nanotubes were prepared as described previously. ${ }^{19}$ In a typical synthesis, $2.00 \mathrm{~g}(25.0 \mathrm{mmol})$ of $\mathrm{TiO}_{2}$ (anatase) were suspended in $60 \mathrm{~mL}$ of $10 \mathrm{~mol} \mathrm{~L}^{-1}$ aqueous $\mathrm{NaOH}$ solution for $30 \mathrm{~min}$. The white suspension formed was transferred to a $90 \mathrm{~mL}$ Teflon-lined stainless steel autoclave and kept at $165 \pm 5{ }^{\circ} \mathrm{C}$ for $170 \mathrm{~h}$. After cooling to room temperature, the resulting white solid was washed several times with deionized water until $\mathrm{pH}$ 11-12 $\left(\mathrm{NTTiO}_{\mathrm{x}}\right)$. For nanoribbon preparation, the same procedure was carried out, except that the temperature that was kept at $190 \pm 5^{\circ} \mathrm{C}\left(\mathrm{NRTiO}_{x}\right)$. After cooling to room temperature, the resulting white solid was washed several times with deionized water until $\mathrm{pH}$ 11-12. Both samples were dried at $60 \pm 10^{\circ} \mathrm{C}$ for $24 \mathrm{~h}$.

\section{Bulk titanate preparation}

The bulk samples of $\mathrm{Na}_{2} \mathrm{Ti}_{3} \mathrm{O}_{7}$ and $\mathrm{Na}_{2} \mathrm{Ti}_{6} \mathrm{O}_{13}$ were synthesized by solid state reactions from the stoichiometric weights of $\mathrm{Na}_{2} \mathrm{CO}_{3}$ and $\mathrm{TiO}_{2}$ (anatase), molar ratios of 1:3 and $1: 6$, respectively, followed by a thermal treatment in tubular furnace at $800^{\circ} \mathrm{C}$ for $20 \mathrm{~h}$, in static air.

\section{Thermal treatment of the nanoribbons}

As-prepared nanoribbons $\left(\mathrm{NRTiO}_{\mathrm{x}}\right)$ were thermally treated in the $100-1000{ }^{\circ} \mathrm{C}$ temperature range in static air using a Mufle type furnace. Each sample was kept at a given temperature for $1 \mathrm{~h}$ in static air.

\section{Characterization techniques}

Determination of $\mathrm{Na}$ and $\mathrm{Ti}$ were carried out by inductively coupled plasma optical emission spectrometry (ICP OES), using a Perkin Elmer Optima 3000 DV, after dissolution of the sample in $0.1 \mathrm{~mol} \mathrm{~L}^{-1} \mathrm{HCl}$. Transmission electron microscopy (TEM) images were obtained using a 
Carl Zeiss CEM-902 setup. Scanning electron microscopy (SEM) images were obtained using a JEOL 6360LV instrument. Energy dispersive X-ray spectroscopy (EDS) data were collected using a Noran system S1X (Thermo Electron Corporation, model 6714A01SUS-SN) probe attached to the scanning electron microscope. X-ray powder diffraction (XRD) patterns were obtained with Shimadzu XRD7000 diffractometer, using $\mathrm{Cu} \mathrm{K}_{\alpha}(\lambda=1.5406 \AA)$ radiation operating with $30 \mathrm{~mA}$ and $40 \mathrm{kV}$. A scan rate of $1^{\circ} \mathrm{min}^{-1}$ was employed. Fourier transform infrared (FTIR) spectroscopy was recorded using the $\mathrm{KBr}$ pellet technique (from 370 up to $1000 \mathrm{~cm}^{-1}$ ) or Nujol mulls between CsI windows (from 250 up to $370 \mathrm{~cm}^{-1}$ ) on a Bomen FTLA 2000 spectrometer. A total of 32 scans and a resolution of $4 \mathrm{~cm}^{-1}$ were employed for getting spectra with good signal to noise ratios. Ex situ Raman spectra were obtained on a Renishaw System 3000 Raman Imaging Microscope using a He-Ne laser $(632.8 \mathrm{~nm})$. In situ Raman spectra data were collected using a Jobin-Yvon T64000 spectrometer, equipped with a cooled charge coupled deviced (CCD) detector using a cw $\mathrm{Ar}^{+}$-ion laser (514.5 nm). Low laser power density was used in order to not overheat the samples. A spectral resolution of $2 \mathrm{~cm}^{-1}$ was used and measurements were performed using a backscattering geometry. DTA-TGA analyses were carried out using a TA equipment, model SDT Q600 over the $25-1000{ }^{\circ} \mathrm{C}$ temperature range with a heating rate of $10^{\circ} \mathrm{C} \mathrm{min}^{-1}$ under an air flow of $100 \mathrm{~mL} \mathrm{~min}^{-1}$.

\section{Results and Discussion}

\section{Structure, composition and morphology}

Figure $1 \mathrm{a}$ and $1 \mathrm{~b}$ shows TEM images of the as-prepared NTTiOx and NRTiOx, respectively. Both samples were prepared via hydrothermal treatment of anatase $\mathrm{TiO}_{2}$ powder in a strongly alkaline $(\mathrm{NaOH})$ environment. Figure 1(a) shows that NTTiOx have a tubular morphology and they are multi-walled with an average outer (inner) diameter of $9 \mathrm{~nm}(5 \mathrm{~nm})$ and a length of several tens of $\mathrm{nm}$. The NTTiOx are open ended (see inset to Figure 1a) with a uniform diameter distribution. In Figure $1 \mathrm{~b}$ we can observe that the NRTiOx samples have a ribbonlike morphology. The NRTiOx are long, uniform and multi-walled with a typical average width of approximately $100 \mathrm{~nm}$, and a length of some micrometers. The nanoribbons present a wide width distribution varying from 20 to $200 \mathrm{~nm}$.

In order to compare the morphological aspects of nanostructured titanates and their bulk counterparts, we show in Figure 2a and 2b SEM images of the as-prepared sodium trititanate $\left(\mathrm{Na}_{2} \mathrm{Ti}_{3} \mathrm{O}_{7}\right)$ and hexatitanate $\left(\mathrm{Na}_{2} \mathrm{Ti}_{6} \mathrm{O}_{13}\right)$,

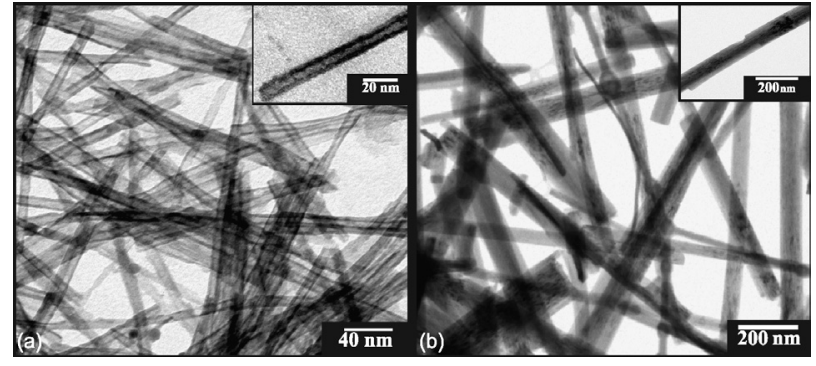

Figure 1. TEM images of as-prepared (a) titanate nanotubes (NTTiOx) and (b), titanate nanoribbons (NRTiOx).

respectively. Both samples have the same morphology and an average particle size of $300 \mathrm{~nm}$ with very large size dispersion.
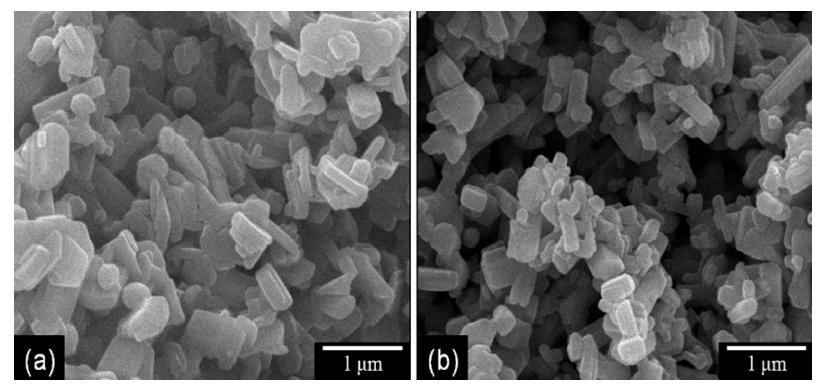

Figure 2. SEM images of (a) bulk trititanate $\left(\mathrm{Na}_{2} \mathrm{Ti}_{3} \mathrm{O}_{7}\right)$ and (b) bulk hexatitanate $\left(\mathrm{Na}_{2} \mathrm{Ti}_{6} \mathrm{O}_{13}\right)$.

The chemical compositions of NTTiOx and NRTiOx samples were investigated by EDS and ICP OES. Table 1 shows the $\mathrm{Na} / \mathrm{Ti}$ molar ratio and the compositions of the samples based on these analyses. The $\mathrm{Na} / \mathrm{Ti}$ ratio found in both NTTiOx and NRTiOx samples probed by EDS are in good agreement with the proposed $\mathrm{Na}_{2-\mathrm{x}} \mathrm{H}_{\mathrm{x}} \mathrm{Ti}_{3} \mathrm{O}_{7}$ chemical composition. ${ }^{19}$ Chemical analysis results of NTTiOx and NRTiOx samples indicated a $\mathrm{Na} / \mathrm{Ti}$ ratio that is consistent with a composition of $\mathrm{Na}_{2} \mathrm{Ti}_{3} \mathrm{O}_{7}$ trititanate rather than bulk $\mathrm{Na}_{2} \mathrm{Ti}_{6} \mathrm{O}_{13}$ hexatitanate.

Table 1. EDS average counts (Na/Ti ratio) for the as-prepared NTTiOx, NRTiOx, $\mathrm{Na}_{2} \mathrm{Ti}_{3} \mathrm{O}_{7}$ and $\mathrm{Na}_{2} \mathrm{Ti}_{6} \mathrm{O}_{13}$ and reference values. $\mathrm{Na} / \mathrm{Ti}$ molar ratios in NTTiOx and NRTiOx obtained by ICP OES are also shown

\begin{tabular}{lccc}
\hline Samples & \multicolumn{2}{c}{$\mathrm{Na} / \mathrm{Ti}$ ratio } & $\begin{array}{c}\text { Predominant } \\
\text { Phase }\end{array}$ \\
& EDS & ICP OES & $\mathrm{Na}_{2} \mathrm{Ti}_{3} \mathrm{O}_{7}$ \\
$\mathrm{Na}_{2} \mathrm{Ti}_{3} \mathrm{O}_{7}$ (bulk) & 0.552 & - & $\mathrm{Na}_{2} \mathrm{Ti}_{6} \mathrm{O}_{13}$ \\
$\mathrm{Na}_{2} \mathrm{Ti}_{6} \mathrm{O}_{13}$ (bulk) & 0.335 & - & $\mathrm{Na}_{2-\mathrm{x}} \mathrm{H}_{\mathrm{x}} \mathrm{Ti}_{3} \mathrm{O}_{7}$ \\
$\mathrm{NTTiOx}_{\text {NRTiOx }}$ & 0.530 & 0.441 & $\mathrm{Na}_{2-\mathrm{x}} \mathrm{H}_{\mathrm{x}} \mathrm{Ti}_{3} \mathrm{O}_{7}$ \\
\hline
\end{tabular}

In Figure 3, we show the XRD patterns of bulk $\left(\mathrm{Na}_{2} \mathrm{Ti}_{3} \mathrm{O}_{7}\right.$ and $\mathrm{Na}_{2} \mathrm{Ti}_{6} \mathrm{O}_{13}$ as prepared) and nanostructured titanates (NTTiOx and NRTiOx as prepared) samples. The XRD pattern of $\mathrm{Na}_{2} \mathrm{Ti}_{3} \mathrm{O}_{7}$ (curve c) exhibits typical peaks for 
a monoclinic structure and the XRD pattern of $\mathrm{Na}_{2} \mathrm{Ti}_{6} \mathrm{O}_{13}$ (curve d) has typical peaks for a base-centered monoclinic structure. ${ }^{26-28}$ In the XRD pattern of $\mathrm{Na}_{2} \mathrm{Ti}_{3} \mathrm{O}_{7}$ (curve c) was observed the presence of small amounts of $\mathrm{TiO}_{2}$ (remainder of the initial solid solution) and $\mathrm{Na}_{2} \mathrm{Ti}_{6} \mathrm{O}_{13}$ (produced by thermal decomposition of $\mathrm{Na}_{2} \mathrm{Ti}_{3} \mathrm{O}_{7}$ ). The XRD pattern of NTTiOx (curve a) is closer to those observed by Chen et al., ${ }^{16}$ with some discrepancies, suggesting a crystalline structure closer to that of $\mathrm{H}_{2} \mathrm{Ti}_{3} \mathrm{O}_{7}$. Thus, we can suggest that NTTiOx has a structure similar to the $\mathrm{Na}_{2} \mathrm{Ti}_{3} \mathrm{O}_{7}$ because of the high concentration of sodium cited in the Table 1. The XRD pattern of NRTiOx (curve b) shows typical peaks that agree well with the XRD pattern of $\mathrm{Na}_{2} \mathrm{Ti}_{3} \mathrm{O}_{7}$ (curve c), given some assumptions. The differences observed in the relative intensity of diffraction peaks for NRTiOx and $\mathrm{Na}_{2} \mathrm{Ti}_{3} \mathrm{O}_{7}$ bulk samples can be related to both texture and size induced effects. The morphology of NTTiOx and NRTiOx (nanometric thickness) samples would prevent the observation of some diffraction peaks owing the breaking of the long range order. The morphology of NRTiOx (large aspect ratio because of the needle shape) certainly would make the powder-like sample more texturized than the bulk where the particles exhibit a more spherical-like shape. Note the possibility of the appearance of some planes of growth in greater intensity than $\mathrm{Na}_{2} \mathrm{Ti}_{3} \mathrm{O}_{7}$ bulk. Regarding NTTiOx, it is expected that the size induced-effects should be more pronounced in a long range probe technique such as X-ray diffraction. The nanometric size is responsible for broadening the diffraction peaks and only the most intense ones observed in the bulk structure can be clearly observed and identified in the XRD patterns of NTTiOx and NRTiOx samples. Furthermore, the peaks close to $10^{\circ}$ are shifted towards lower $2 \theta$ values, indicating an increase in the interlayer distances because of the curvature effects (in NTTiOx) and ionic balance in the layers. In case of NTTiOx samples the curvature effects induces a unit cell distortion which is one of those responsible for asymmetrical broadening of the peaks as compared with bulk titanates. ${ }^{29}$

\section{Vibrational properties}

In order to study the vibrational properties of titanate nanostructures we first review the Group Theory Analysis of vibrations for $\mathrm{Na}_{2} \mathrm{Ti}_{3} \mathrm{O}_{7}$ and $\mathrm{Na}_{2} \mathrm{Ti}_{6} \mathrm{O}_{13}$ bulk structures. Bulk $\mathrm{Na}_{2} \mathrm{Ti}_{3} \mathrm{O}_{7}$ at room temperature exhibits a lamellar structure (monoclinic, space group $\mathrm{P} 2 / \mathrm{m}\left(\mathrm{C}_{2 \mathrm{~h}}{ }^{2}\right)$ ) with two formulas per unit cell $(Z=2)$. Group theory predicts that $\mathrm{Na}_{2} \mathrm{Ti}_{3} \mathrm{O}_{7}$ would exhibit 69 vibrational modes distributed among the irreducible representations as follows: $15 \mathrm{~A}_{\mathrm{g}}+$ $20 \mathrm{~A}_{\mathrm{u}}+15 \mathrm{~B}_{\mathrm{g}}+19 \mathrm{~B}_{\mathrm{u}}$. Bulk Na $\mathrm{Ti}_{6} \mathrm{O}_{13}$ at room temperature

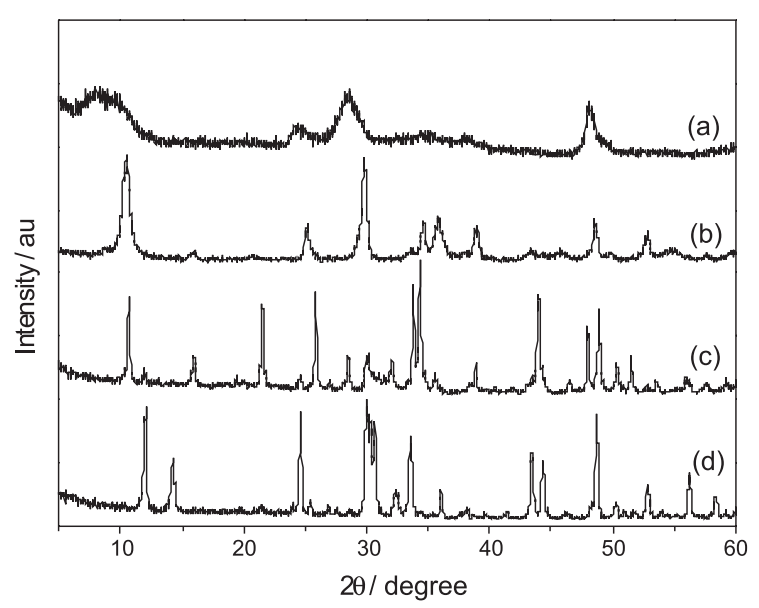

Figure 3. XRD patterns of as-prepared (a) titanate nanotubes (NTTiOx) (b), titanate nanoribbons (NRTiOx) (c), bulk $\mathrm{Na}_{2} \mathrm{Ti}_{3} \mathrm{O}_{7}$ and (d) bulk $\mathrm{Na}_{2} \mathrm{Ti}_{6} \mathrm{O}_{13}$.

has a tunnel-like structure (base-centered monoclinic, space group $\mathrm{C} 2 / \mathrm{m}\left(\mathrm{C}_{2 \mathrm{~h}}{ }^{3}\right)$ ) with two formulas per unit cell $(\mathrm{Z}=2)$, whose vibrational mode distribution is $12 \mathrm{~A}_{\mathrm{g}}+18 \mathrm{~A}_{\mathrm{u}}+$ $12 \mathrm{~B}_{\mathrm{g}}+18 \mathrm{~B}_{\mathrm{u}}$. Both $\mathrm{A}_{\mathrm{g}}\left(\mathrm{A}_{\mathrm{u}}\right)$ and $\mathrm{B}_{\mathrm{g}}\left(\mathrm{B}_{\mathrm{u}}\right)$ are Raman (IR) active representations.

In Figure 4, we show FTIR spectra for titanate (bulk and nanostructured) samples. The FTIR spectrum of $\mathrm{Na}_{2} \mathrm{Ti}_{3} \mathrm{O}_{7}$ (curve c) and $\mathrm{Na}_{2} \mathrm{Ti}_{6} \mathrm{O}_{13}$ (curve d) are distinctively different from each other and they are in agreement with previous reports. ${ }^{25,30,31}$ The FTIR spectrum of $\mathrm{Na}_{2} \mathrm{Ti}_{3} \mathrm{O}_{7}$ shows eight bands and two shoulders (408 and $445 \mathrm{~cm}^{-1}$ ) which can be assigned (in order of increasing wavenumber) as being lattice modes and $\mathrm{Na}-\mathrm{O}-\mathrm{Ti}$ bonds (below $300 \mathrm{~cm}^{-1}$ ), $\mathrm{TiO}_{6}$ octahedron modes (in the $300-1000 \mathrm{~cm}^{-1}$ range). Besides a less intensity, the spectrum of $\mathrm{Na}_{2} \mathrm{Ti}_{6} \mathrm{O}_{13}$ shows five broad bands whose assignment is similar to that of $\mathrm{Na}_{2} \mathrm{Ti}_{3} \mathrm{O}_{7}$. It is clear that the number of vibrational bands observed for $\mathrm{Na}_{2} \mathrm{Ti}_{3} \mathrm{O}_{7}$ is larger than for $\mathrm{Na}_{2} \mathrm{Ti}_{6} \mathrm{O}_{13}$, in agreement with group theory prediction. The FTIR spectrum of NTTiOx (curve a) is characterized by three broad bands located at about 287,470 and $895 \mathrm{~cm}^{-1}$ and two shoulders at 340 and $520 \mathrm{~cm}^{-1}$. The spectrum of NRTiOx (curve b) shows five bands located at about 297, 338, 465, 673 and $905 \mathrm{~cm}^{-1}$ and shoulders in 780 and $845 \mathrm{~cm}^{-1}$. NTTiOx and NRTiOx bands are very close in energy to those of bulk $\mathrm{Na}_{2} \mathrm{Ti}_{3} \mathrm{O}_{7}$ except for the bands located at about $338 \mathrm{~cm}^{-1}$ (for NRTiOx). The differences between the nanoparticles (NTTiOx and NRTiOx) and $\mathrm{Na}_{2} \mathrm{Ti}_{3} \mathrm{O}_{7}$ can be attributed to the diameter of a few nanometers, the curvature effects, unit cell distortion in the [010] direction and the stress placed on the surface of the nanometric particles. The FTIR bands of NTTiOx and NRTiOx are closer in energy density to the trititanate spectrum, but they cannot be appointed as having similar structure to the $\mathrm{Na}_{2} \mathrm{Ti}_{3} \mathrm{O}_{7}$ bulk based in FTIR measurements. ${ }^{11,14,32}$ 


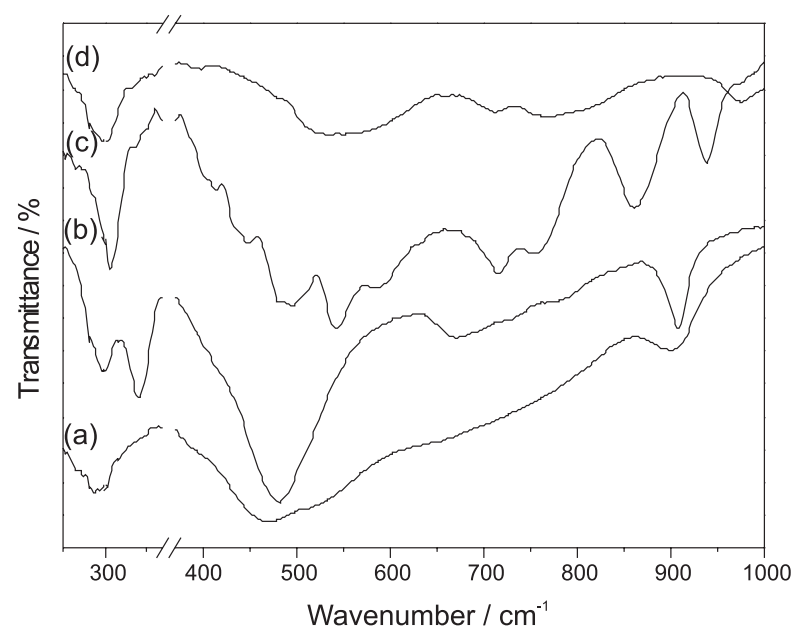

Figure 4. FTIR spectra for as-prepared (a) titanate nanotubes (NTTiOx), (b) titanate nanoribbons (NRTiOx), (c) bulk $\mathrm{Na}_{2} \mathrm{Ti}_{3} \mathrm{O}_{7}$ and (d) bulk $\mathrm{Na}_{2} \mathrm{Ti}_{6} \mathrm{O}_{13}$.

In Figure 5, we show Raman spectra for both nanostructured and bulk titanate samples. The Raman spectra for nanostructured samples are much weaker in intensity than for bulk samples. The Raman spectrum of bulk $\mathrm{Na}_{2} \mathrm{Ti}_{3} \mathrm{O}_{7}$ (curve c) and $\mathrm{Na}_{2} \mathrm{Ti}_{6} \mathrm{O}_{13}$ (curve d) are similar to those reported in the literature. ${ }^{33-35}$ Again the relative number of modes observed for $\mathrm{Na}_{2} \mathrm{Ti}_{3} \mathrm{O}_{7}$ and $\mathrm{Na}_{2} \mathrm{Ti}_{6} \mathrm{O}_{13}$ are in agreement with group theory predictions. We observed that both NTTiOx and NRTiOx have different Raman spectra with respect to the number of bands, but they are similar with regard to location of energy bands. The differences can be understood through the following statements. First, the bands are broader in NTTiOx and this can be understood in terms of size-induced effects which break the $\mathrm{q} c a .0$ momentum conservation rule that allow phonons from the interior of the Brillouin zone to contribute to the Raman response. Second, disorder and curvature effects which induce unit cell distortion would also contribute to such broadening. Based on Raman spectroscopy and on these statements we can state that the structure of NTTiOx and NRTiOx are similar, differing only by the definition of their Raman bands. The Raman spectrum of NTTiOx exhibits vibrational frequencies at about 156,193 and $276 \mathrm{~cm}^{-1}$ which can be assigned to lattice modes and Na-O-Ti modes. Bands at about 445, 656 and $781 \mathrm{~cm}^{-1}$ are assigned to vibrations from $\mathrm{TiO}_{6}$ octahedron while the band at about $905 \mathrm{~cm}^{-1}$ is related to terminal Ti-O bonds (stretchings) either directed to the interlayer space or to the outer surface of the nanotube. ${ }^{20,36-42}$ In the Raman spectrum of NRTiOx the peaks are more defined than those for NTTiOx because of their larger size and less distortion of the layers (no curvature effect) thus showing a better atomic ordering in the layers. Different from the NTTiOx, the Raman spectrum of NRTiOx presents more vibrational peaks and this is related to the better crystallinity which allows more modes to be solved in the Raman spectrum. The assignment of the modes is similar to what was proposed for NTTiOx. The Raman mode at about $920 \mathrm{~cm}^{-1}$ which is assigned to terminal Ti-O bonds, is also observed in NRTiOx. The relative intensity of this mode for both NRTiOx and NTTiOx is higher than for bulk $\mathrm{Na}_{2} \mathrm{Ti}_{3} \mathrm{O}_{7}$, which is consistent with the morphology since low dimensional structures would have larger surface to volume ratios. ${ }^{36,38,41}$ Furthermore, this band is more pronounced for NTTiOx than for NRTiOx, thus indicating that, for nanotubes, there are more Ti-O terminal bonds because they can be directed either inward or outward from the layer. We cannot determine with good precision the structure of the NTTiOx and NRTiOx through vibrational spectroscopy at room temperature. Thus, in the next section we studied the behavior of the NRTiOx through it thermal decomposition and the structural changes facing the thermal treatment can be determined with greater precision.

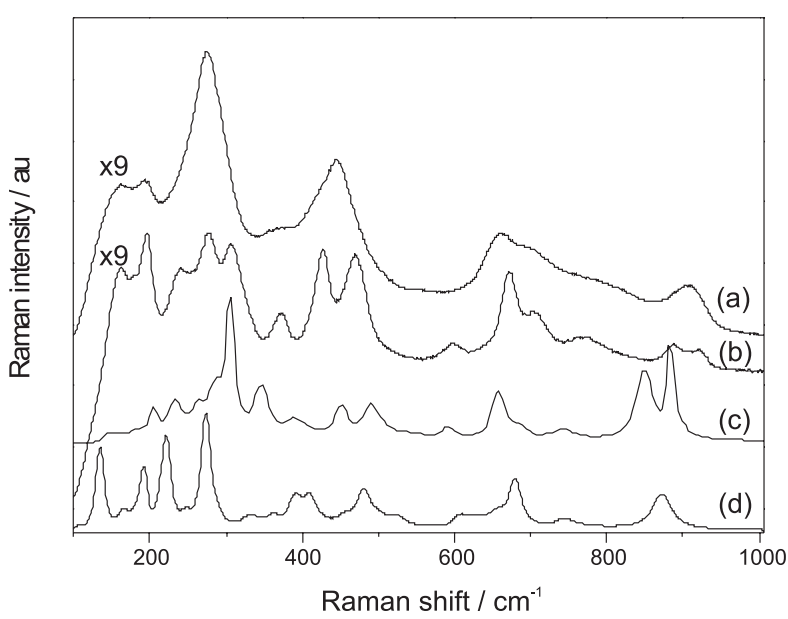

Figure 5. Room temperature Raman spectra of as-prepared (a) titanate nanotubes (NTTiOx), (b) titanate nanoribbons (NRTiOx), (c) bulk $\mathrm{Na}_{2} \mathrm{Ti}_{3} \mathrm{O}_{7}$ and (d) bulk $\mathrm{Na}_{2} \mathrm{Ti}_{6} \mathrm{O}_{13}$.

\section{Thermal decomposition behavior}

In Figure 6a, we show the in situ Raman spectrum of NRTiOx with the temperature varying from room temperature (RT) up to $550{ }^{\circ} \mathrm{C}$. Changes in the Raman bands for the NRTiOx are observed for temperature close to $200{ }^{\circ} \mathrm{C}$. Two well resolved bands (175 and $200 \mathrm{~cm}^{-1}$ ) become broader collapsing to an asymmetric band. These results point to the structural water release, which is consistent with DTA-TGA measurements (not shown here). By further increasing the temperature, we note gradual changes in the Raman bands regarding the broadening of the peaks. However, close to $300{ }^{\circ} \mathrm{C}$ we can observe that the structural water release induced a structural disorder in 
the system. This can be associated to the onset of a gradual phase transformation at higher temperatures. It is clear that heating to $550{ }^{\circ} \mathrm{C}$ introduced changes in the sample structure. We show at the top of Figure 6a the Raman spectrum of the NRTiOx at room temperature after cooling (RT cooled). It is clear that the structure of the sample has been modified because the peaks marked with arrows in the spectrum of the as prepared sample are absent in the annealed sample. This issue is further addressed by ex situ Raman data for which the samples were treated at higher temperatures, as we discuss next.

In Figure 6b, we show ex situ Raman data, for which samples were annealed in the 100 to $1000{ }^{\circ} \mathrm{C}$ temperature range. We can also observe changes in the Raman bands close to the annealing temperature of $200{ }^{\circ} \mathrm{C}$, related to structural water release. This water release probably generates changes in the structure of the samples that were affected by this phenomenon. In the $300-600{ }^{\circ} \mathrm{C}$ temperature range annealing we can observe only slight changes that can be related with release of hydroxyl groups adsorbed on the surface of the titanate nanoribbons, these same slight changes were observed in the titanates nanotubes. ${ }^{19}$ In the Raman bands from the sample heated to close to $800{ }^{\circ} \mathrm{C}$ we can notice a remarkable change in the Raman spectrum (marked by up arrows), indicating a partial phase transformation to bulk $\mathrm{Na}_{2} \mathrm{Ti}_{6} \mathrm{O}_{13}$. In the same temperature range was complicated to observe the emergence of the bands related to the bulk $\mathrm{Na}_{2} \mathrm{Ti}_{3} \mathrm{O}_{7}$ because of the superposition of bulk bands. The spectral features of bulk $\mathrm{Na}_{2} \mathrm{Ti}_{6} \mathrm{O}_{13}$ and $\mathrm{Na}_{2} \mathrm{Ti}_{3} \mathrm{O}_{7}$ gain intensity close to $1000{ }^{\circ} \mathrm{C}$, indicating that NRTiOx were converted to bulk structures. This is further confirmed by the disappearance of the $920 \mathrm{~cm}^{-1}$ peak (see down arrows) which is a spectral signature of NRTiOx morphology. This peak can be used to identify the titanate morphology and its changes upon thermal treatment.

In order to support this conclusion we also investigated the thermal decomposition behavior of NRTiOx using XRD. From the X-ray diffraction patterns shown in Figure 7 the release of structural water from the NRTiOx structure at about $200{ }^{\circ} \mathrm{C}$ is clearly observed. Water removal for samples treated at 200 and $300{ }^{\circ} \mathrm{C}$ caused the diffraction peak at $10^{\circ}$ to be shifted toward larger $2 \theta$ values, thus indicating an interlayer contraction. For samples treated at $300{ }^{\circ} \mathrm{C}$ (see up arrow) we can observe the appearance of a peak close to $2 \theta=12^{\circ}$ which is typical of the bulk $\mathrm{Na}_{2} \mathrm{Ti}_{6} \mathrm{O}_{13}$ structure and a sharp drop in the relative intensity of the peak at about $2 \theta=10^{\circ}$ which is typical of a $\mathrm{Na}_{2} \mathrm{Ti}_{3} \mathrm{O}_{7}$ phase. This can confirm that NRTiOx sample, which has structure close to $\mathrm{Na}_{2-\mathrm{x}} \mathrm{H}_{\mathrm{x}} \mathrm{Ti}_{3} \mathrm{O}_{7}$, when thermally treated between $200^{\circ} \mathrm{C}$ and $300{ }^{\circ} \mathrm{C}$ some of the nanoribbons loose interlayer water. This
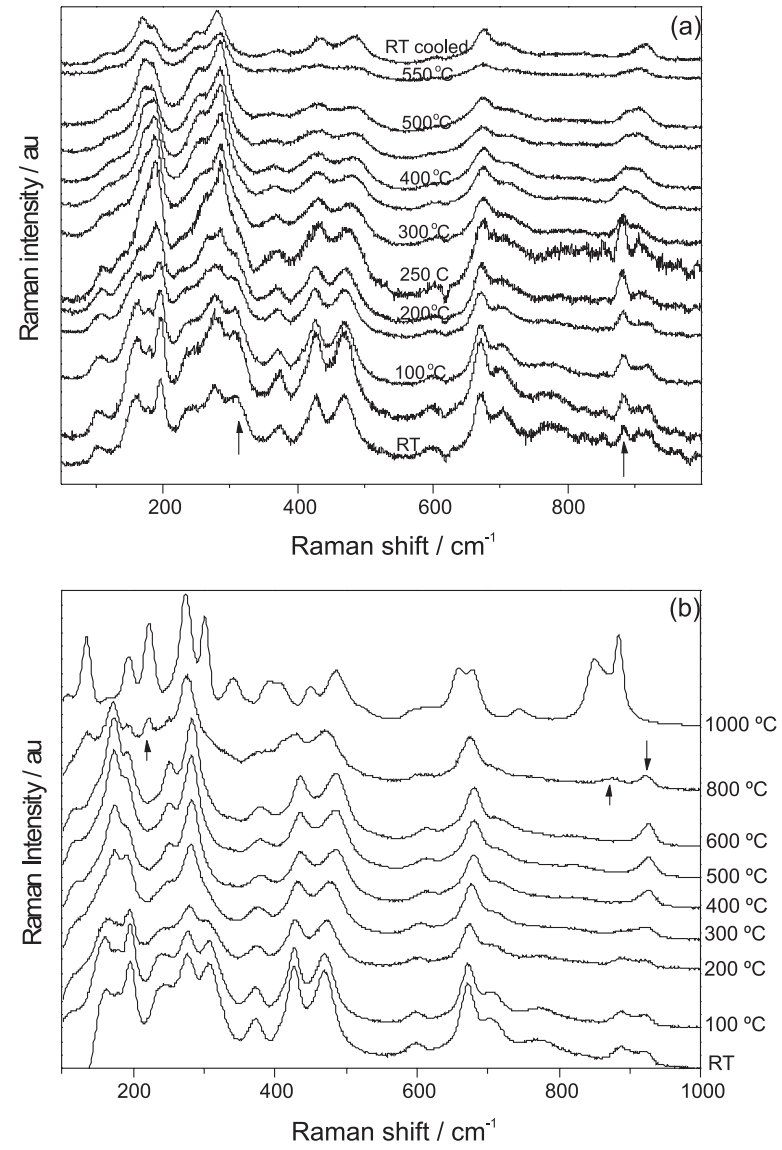

Figure 6. Raman spectra (a) in situ for NRTiOx for the room temperature (RT) to $550{ }^{\circ} \mathrm{C}$ temperature range and (b) ex situ for NRTiOx in the $100-1000{ }^{\circ} \mathrm{C}$ temperature range.

water releasing allowed a gradual phase transformation to occur in the nanoribbons leading to structure which is similar to the $\mathrm{Na}_{2} \mathrm{Ti}_{6} \mathrm{O}_{13}$ bulk for temperatures higher than $600{ }^{\circ} \mathrm{C}$. The rest of the nanoribbons which are anhydrous or contains a small amount of water due to a higher $\mathrm{Na}$ concentration does not undergo both phase and morphological changes up to $600{ }^{\circ} \mathrm{C}$. This behavior leads to diffraction pattern to be dominated by peaks from $\mathrm{Na}_{2} \mathrm{Ti}_{6} \mathrm{O}_{13}$ bulk, because they have a higher long range order than the NRTiOx nanoparticles. It is observed that in the $300-600^{\circ} \mathrm{C}$ temperature range a structural disorder develops in the XRD pattern and it can be understood as being due to structural rearrangements of the part of NRTiOx as a consequence of water and hydroxyl release which possibly induce morphological changes in the nanoribbons. At $800{ }^{\circ} \mathrm{C}$ a strong change in the NRTiOx X-ray pattern is observed in agreement with Raman spectroscopy data. The NRTiOx $\mathrm{X}$-ray pattern changes to a pattern that resembles that of a phase mixing of bulk $\mathrm{Na}_{2} \mathrm{Ti}_{3} \mathrm{O}_{7}$ and $\mathrm{Na}_{2} \mathrm{Ti}_{6} \mathrm{O}_{13}$. This assertion is based on the appearance of the diffraction peaks close to $2 \theta=10^{\circ}$ and $26^{\circ}$ (marked with $\mathrm{x}$ ) which are typical of bulk $\mathrm{Na}_{2} \mathrm{Ti}_{3} \mathrm{O}_{7}$ as well as the appearance of three peaks 
(marked with $\mathrm{O}$ in Figure 7) close to $12^{\circ}, 25^{\circ}$ and $31^{\circ}$ that are typical of bulk $\mathrm{Na}_{2} \mathrm{Ti}_{6} \mathrm{O}_{13}$. At $1000^{\circ} \mathrm{C}$ the peaks become well defined and we clearly identify $\mathrm{Na}_{2} \mathrm{Ti}_{3} \mathrm{O}_{7}$ (marked with $\mathrm{x}$ ) and $\mathrm{Na}_{2} \mathrm{Ti}_{6} \mathrm{O}_{13}$ (marked with $\mathrm{O}$ ) phase mixing. It is observed that the amount of bulk phase $\mathrm{Na}_{2} \mathrm{Ti}_{3} \mathrm{O}_{7}$ is larger than that of $\mathrm{Na}_{2} \mathrm{Ti}_{6} \mathrm{O}_{13}$. This could be indicative of the gradual conversion of a portion (lower portion) of the NRTiOx nanoparticles after dehydration to the bulk $\mathrm{Na}_{2} \mathrm{Ti}_{6} \mathrm{O}_{13}$ from $300{ }^{\circ} \mathrm{C}$ and the conversion of the remaining NRTiOx nanoparticles to bulk phase $\mathrm{Na}_{2} \mathrm{Ti}_{3} \mathrm{O}_{7}$ from about $800{ }^{\circ} \mathrm{C}$, as discussed for NTTiOx in the literature..$^{23}$ The thermal decomposition of titanate nanotubes leads to similar results, which confirm that both nanoribbons and nanotubes have similar layer structures and compositions at room temperature. ${ }^{19,25-28,30,43,44}$ Papp et al. ${ }^{25}$ studied the thermal evolution of the $\mathrm{Na}_{2} \mathrm{Ti}_{3} \mathrm{O}_{7}$ bulk, and they observed that as temperature increase the $\mathrm{Na}_{2} \mathrm{Ti}_{3} \mathrm{O}_{7}$ structure is partially dymerized to form the $\mathrm{Na}_{2} \mathrm{Ti}_{6} \mathrm{O}_{13}$, which is similar to what we observed for NRTiOx samples. This provides further evidence that the atomic arrangement in the layers of NRTiOx is similar to $\mathrm{Na}_{2} \mathrm{Ti}_{3} \mathrm{O}_{7}$ bulk.

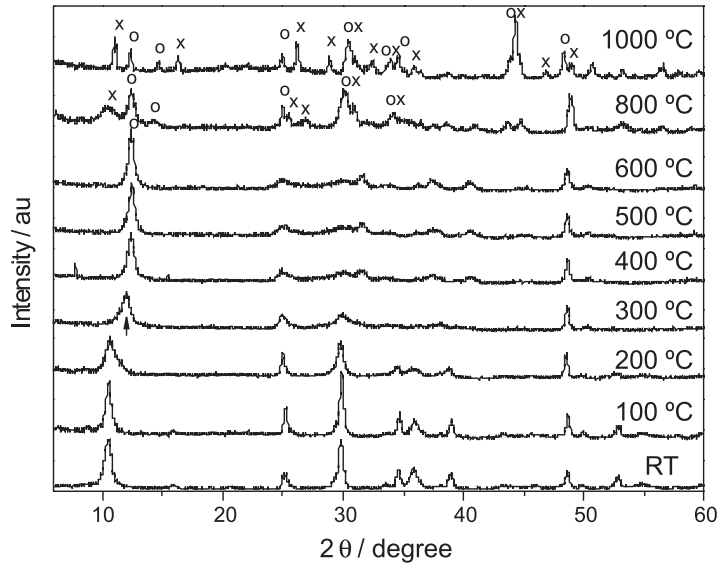

Figure 7. Ex situ XRD patterns for NRTiOx in the $100-1000{ }^{\circ} \mathrm{C}$ temperature range. $(\mathrm{x})$ and (o) stand for $\mathrm{Na}_{2} \mathrm{Ti}_{3} \mathrm{O}_{7}$ and $\mathrm{Na}_{2} \mathrm{Ti}_{6} \mathrm{O}_{13}$ phases, respectively.

In Figure 8, we show ex situ FTIR spectra of NRTiOx thermally treated in the 100 to $1000{ }^{\circ} \mathrm{C}$ temperature interval. From room temperature up to $800{ }^{\circ} \mathrm{C}$ the FTIR spectra do not exhibit any significant changes (up arrows) that might be observed. At $1000{ }^{\circ} \mathrm{C}$ we can verify (down arrows) the direct phase transformation which results in a phase mixing of bulk $\mathrm{Na}_{2} \mathrm{Ti}_{3} \mathrm{O}_{7}$ and $\mathrm{Na}_{2} \mathrm{Ti}_{6} \mathrm{O}_{13}$ for the thermally treated NRTiOx sample.

In Figure 9a we show SEM images of as-prepared NRTiOx and in 9b samples treated at 800 and in 9c at $1000{ }^{\circ} \mathrm{C}$. We can clearly observe that thermal annealing at $1000{ }^{\circ} \mathrm{C}$ induced morphology changes thus indicating the formation of large rods (bulk-like) with a phase

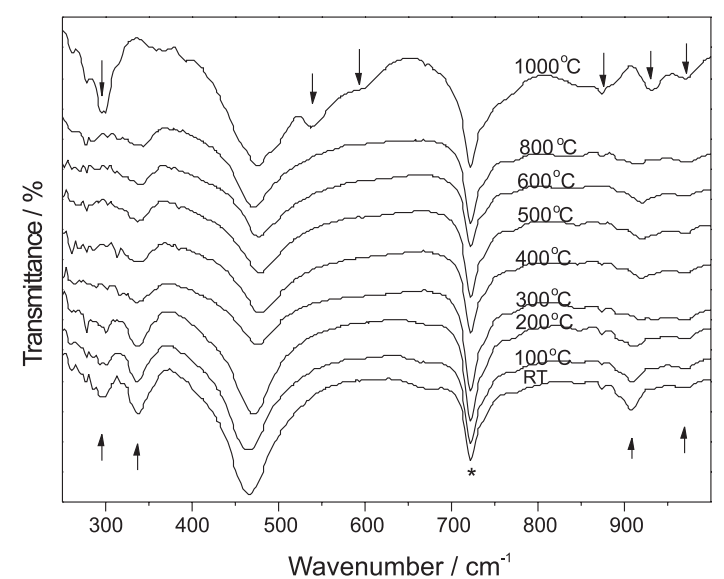

Figure 8. Ex situ FTIR spectra for NRTiOx thermally treated in the 100$1000^{\circ} \mathrm{C}$ temperature range. $(*)$ Nujol absorption band.

mixing of bulk $\mathrm{Na}_{2} \mathrm{Ti}_{3} \mathrm{O}_{7}$ and $\mathrm{Na}_{2} \mathrm{Ti}_{6} \mathrm{O}_{13}$. By comparing the results obtained from Raman, FTIR, and XRD we can see that Raman spectroscopy can track the structure and morphology changes very clearly. Since these experiments are simpler, less time consuming and non-destructive, we can use Raman spectroscopy for investigating both structure and morphology of titanates nanostructures.
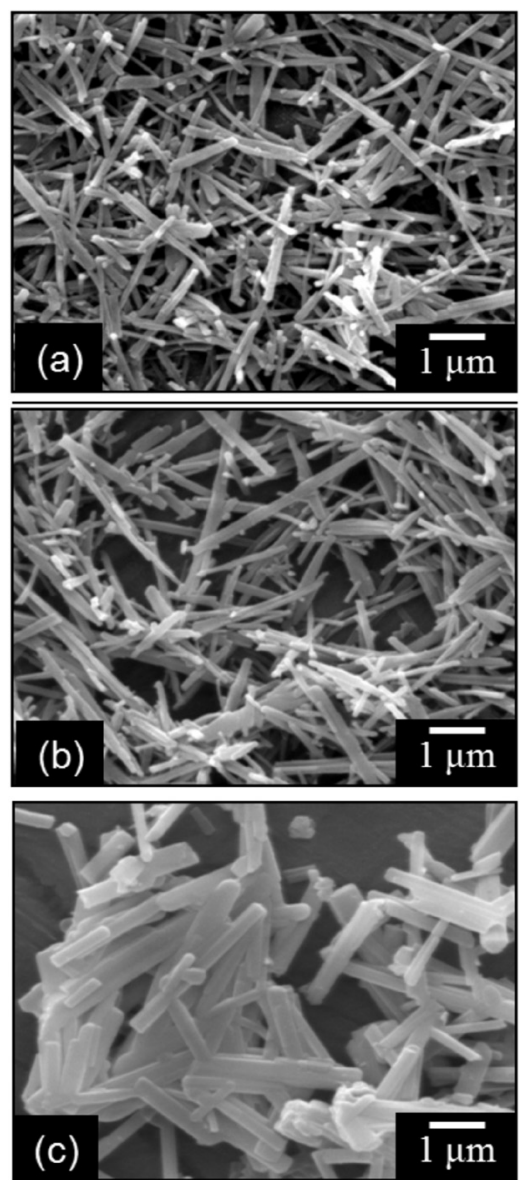

Figure 9. SEM images of (a) as-prepared NRTiOx at room temperature and thermally treated at (b) 800 and (c) $1000{ }^{\circ} \mathrm{C}$. 


\section{Conclusions}

We have discussed the structural, morphological and vibrational properties of titanate nanostructures (nanotubes and nanoribbons). The vibrational spectra of NTTiOx and NRTiOx exhibit clear signatures which mean that both the morphology and the size of these nanostructures play key roles in the vibrational modes, allowing the use of both Raman and FTIR to identify the morphologies of the titanates nanostructures.

We also have studied the thermal decomposition properties of titanate nanoribbons obtained via the hydrothermal method. The thermal annealing of these titanate nanostructures at increasing temperatures leads to several structural modifications. At about $200{ }^{\circ} \mathrm{C}$ the interlamelar water is released and the interlayer distance is reduced. At about $300{ }^{\circ} \mathrm{C}$ and with the release of the water the material starts to undergo a gradual phase transformation to the bulk $\mathrm{Na}_{2} \mathrm{Ti}_{6} \mathrm{O}_{13}$, observed in both Raman and X-ray data, which show that the samples get disordered. Part of the nanoribbons (the dominant fraction) does not undergo any phase transformation up to $600{ }^{\circ} \mathrm{C}$, and after this temperature they change directly to $\mathrm{Na}_{2} \mathrm{Ti}_{3} \mathrm{O}_{7}$ bulk. By further increasing the annealing temperature the structural changes become prominent and at about $800^{\circ} \mathrm{C}$ the presence of bulk $\mathrm{Na}_{2} \mathrm{Ti}_{3} \mathrm{O}_{7}$ and $\mathrm{Na}_{2} \mathrm{Ti}_{6} \mathrm{O}_{13}$ phase mixing is observed. For samples treated at $1000{ }^{\circ} \mathrm{C}$ we observed an increase in the amount of NRTiOx transformed in bulk $\mathrm{Na}_{2} \mathrm{Ti}_{3} \mathrm{O}_{7}$ phase. This may be related to a greater concentration of interlamellar sodium in each NRTiOx, generating a greater stability with the increase of the treatment temperature. Besides the structural changes of the nanoribbons samples thermally treated are directly related to changes in their morphology that evolves to large rods are also observed. Both structural and morphological properties that have changed with thermal treatment were clearly captured in Raman spectra, thus suggesting that this technique can be used to precisely monitor the thermal behavior of titanate nanoribbons. Finally, this paper contributes to improve the understanding of titanate nanostructures through an assessment of their thermal decomposition behavior. The NTTiOx and NRTiOx have similar layer structures that corroborate with the $\mathrm{Na}_{2-\mathrm{x}} \mathrm{H}_{\mathrm{x}} \mathrm{Ti}_{3} \mathrm{O}_{7}$ composition already mentioned.

\section{Acknowledgments}

Financial support from the Brazilian funding agencies CNPq, CAPES, FUNCAP and FAPESP is gratefully acknowledged. A.G.S.F. acknowledges CNPq (grant 306335/2007-7) for financial support. The authors are indebted to Dr. Carlos A. P. Leite for assistance with the
TEM images and to Prof. C. H. Collins (IQ-UNICAMP, Brazil) for English revision. Bartolomeu C. Viana thanks to the Laboratório Nacional de Luz Sincrotron (LNLS) for training in transmission electron microscope. This is a contribution of Millennium Institute of Complex Materials (PADCT/MCT) and the Rede Nacional de Pesquisa em Nanotubos de Carbono-CNPq/MCT.

\section{References}

1. Remskar, M.; Adv. Mater. 2004, 16, 1497.

2. Tenne, R.; Nat. Nanotechnol. 2006, 1, 103.

3. Chen, X.; Mao, S. S.; Chem. Rev. 2007, 107, 2891.

4. Idakiev, V.; Yuan, Z. Y.; Tabakova, T.; Su, B. L.; Appl. Catal., A 2005, 281, 149.

5. Li, J. R.; Tang, Z. L.; Zhang, Z. T.; Electrochem. Commun. 2005, 7, 62 .

6. Kuang, D.; Brillet, J.; Chen, P.; Takata, M.; Uchida, S.; Miura, H.; Sumioka, K.; Zakeeruddin, S. M.; Gratzel, M.; ACS Nano 2008, 2, 1113 .

7. Fang, D.; Huanh, K.; Liu, S.; Huang, J.; J. Braz. Chem. Soc. 2008, 19, 1059.

8. Ferreira, O. P., PhD Thesis, Universidade Estadual de Campinas, Brazil, 2006.

9. Lee, C. K.; Liu, S. S.; Juang, L. C.; Wang, C. C.; Lyu, M. D.; Hung, S. H.; J. Hazard. Mater. 2007, 148, 756.

10. Kasuga, T.; Hiramatsu, M.; Hoson, A.; Sekino, T.; Niihara, K.; Adv. Mater. 1999, 11, 1307.

11. Wang, Y. Q.; Hu, G. Q.; Duan, X. F.; Sun, H. L.; Xue, Q. K.; Chem. Phys. Lett. 2002, 365, 427.

12. Yao, B. D.; Chan, Y. F.; Zhang, X. Y.; Zhang, W. F.; Yang, Z. Y.; Wang, N.; Appl. Phys. Lett. 2003, 82, 281.

13. Zhang, S.; Peng, L. M.; Chen, Q.; Du, G. H.; Dawson, G.; Zhou, W. Z.; Phys. Rev. Lett. 2003, 91, 2561031.

14. Bavykin, D. V.; Parmon, V. N.; Lapkin, A. A.; Walsh, F. C.; J. Mater. Chem. 2004, 14, 3370.

15. Zhang, S.; Chen, Q.; Peng, L. M.; Phys. Rev. B: Condens. Matter Mater. Phys. 2005, 71.

16. Chen, Q.; Du, G. H.; Zhang, S.; Peng, L. M.; Acta Crystallogr., Sect. B: Struct. Sci. 2002, 58, 587.

17. Yuan, Z. Y.; Su, B. L.; Colloids Surf., A 2004, 241, 173.

18. Wei, M. D.; Qi, Z. M.; Ichihara, M.; Honma, I.; Zhou, H. S.; J. Nanosci. Nanotechnol. 2007, 7, 1065.

19. Ferreira, O. P.; Souza, A. G.; Mendes, J.; Alves, O. L.; J. Braz. Chem. Soc. 2006, 17, 393.

20. Menzel, R.; Peiro, A. M.; Durrant, J. R.; Shaffer, M. S. P.; Chem. Mater. 2006, 18, 6059.

21. Cao, J.; Choi, J.; Musfeldt, J. L.; Lutta, S.; Whittingham, M. S.; Chem. Mater. 2004, 16, 731.

22. Horvath, E.; Kukovecz, A.; Konya, Z.; Kiricsi, I.; Chem. Mater. 2007, 19, 927 . 
23. Morgado, E.; de Abreu, M. A. S.; Pravia, O. R. C.; Marinkovic, B. A.; Jardim, P. M.; Rizzo, F. C.; Araujo, A. S.; Solid State Sci. 2006, $8,888$.

24. Wu, D.; Liu, J.; Zhao, X. N.; Li, A. D.; Chen, Y. F.; Ming, N. B.; Chem. Mater. 2006, 18, 547.

25. Papp, S.; Korosi, L.; Meynen, V.; Cool, P.; Vansant, E. F.; Dekany, I.; J. Solid State Chem. 2005, 178, 1614.

26. Andersson, S.; Wadsley, A. D.; Acta Crystallogr. 1961, 14, 1245.

27. Andersson, S.; Wadsley, A. D.; Acta Crystallogr. 1962, 15, 194.

28. Ramirez-Salgado, J.; Djurado, E.; Fabry, P.; J. Eur. Ceram. Soc. 2004, 24, 2477.

29. Andreev, Y. G.; Bruce, P. G.; J. Am. Chem. Soc. 2008, 130, 9931.

30. Bobrova, A. M. Z., I.G.;Bragina, M. I.; Fotiev, A. A.; J. Appl. Spectrosc. 1968, 8.

31. Peng, G. W.; Liu, H. S.; Mater. Chem. Phys. 1995, 42, 264.

32. Sun, X. M.; Li, Y. D.; Chem.-Eur. J. 2003, 9, 2229.

33. Bamberger, C. E.; Begun, G. M.; J. Am. Ceram. Soc. 1987, 70, C48.

34. Su, Y.; Balmer, M. L.; Bunker, B. C.; J. Phys. Chem. B 2000 , 104,8160 .
35. Kolen'ko, Y. V.; Kovnir, K. A.; Gavrilov, A. I.; Garshev, A. V.; Frantti, J.; Lebedev, O. I.; Churagulov, B. R.; Van Tendeloo, G.; Yoshimura, M.; J. Phys. Chem. B 2006, 110, 4030.

36. Meng, X. D.; Wang, D. Z.; Liu, J. H.; Zhang, S. Y.; Mater. Res. Bull. 2004, 39, 2163.

37. Liu, X. Y.; Coville, N. J.; S. Afr. J. Chem. 2005, 58, 110.

38. Ma, R. Z.; Fukuda, K.; Sasaki, T.; Osada, M.; Bando, Y.; J. Phys. Chem. B 2005, 109, 6210.

39. Bavykin, D. V.; Friedrich, J. M.; Lapkin, A. A.; Walsh, F. C.; Chem. Mater. 2006, 18, 1124.

40. Qamar, M.; Yoon, C. R.; Oh, H. J.; Kim, S. J.; Kim, D. H.; Lee, K. S.; Lee, H. G.; J. Korean Phys. Soc. 2006, 49, 1493.

41. Zarate, R. A.; Fuentes, S.; Wiff, J. P.; Fuenzalida, V. M.; Cabrera, A. L.; J. Phys. Chem. Solids 2007, 68, 628.

42. Morgado, E.; de Abreu, M. A. S.; Moure, G. T.; Marinkovic, B. A.; Jardim, P. M.; Araujo, A. S.; Mater. Res. Bull. 2007, 42, 1748.

43. Yu, H. G.; Yu, J. G.; Cheng, B.; Zhou, M. H.; J. Solid State Chem. 2006, 179, 349.

44. Sun, X. M.; Chen, X.; Li, Y. D.; Inorg. Chem. 2002, 41, 4996.

Received: August 4. 2008

Web Release Date: November 28, 2008

FAPESP helped in meeting the publication costs of this article. 